medRxiv preprint doi: https://doi.org/10.1101/2021.03.24.21253807; this version posted March 26, 2021. The copyright holder for this preprint (which was not certified by peer review) is the author/funder, who has granted medRxiv a license to display the preprint in All rights reserved. No reuse allowed without permission.

1 Impact of the COVID-19 Pandemic on Antimicrobial Resistance (AMR) Surveillance,

\title{
Prevention and Control: A Global Survey
}

3

4 Tomczyk, Sara ${ }^{1 *}$, Taylor, Angelina ${ }^{1}$, Brown, Allison ${ }^{2}$, de Kraker, Marlieke3, Eckmanns, Tim¹ ${ }^{1}$ El-

5 Saed, Aiman ${ }^{4}$, Alshamrani, Majid ${ }^{4}$, Hendriksen, Rene ${ }^{5}$, Jacob, Megan ${ }^{6}$, Löfmark, Sonja7,

6 Perovic, Olga ${ }^{8}$, Shetty, Nandini ${ }^{9}$, Sievert, Dawn ${ }^{2}$, Smith, Rachel ${ }^{2}$, Stelling, John ${ }^{10}$, Thakur,

7 Siddhartha ${ }^{6}$, Tornimbene, Barbara ${ }^{11}$, Vietor, Ann Christin ${ }^{1}$, Eremin, Sergey ${ }^{11}$, on behalf of the

8 WHO AMR Surveillance and Quality Assessment Collaborating Centre Network

9

1. Robert Koch Institute, WHO Collaborating Center for Emerging Infections and Biological Threats, Berlin, Germany

2. Centers for Disease Control and Prevention, WHO Collaborating Centre for International Monitoring of Bacterial Resistance to Antimicrobial Agents, Atlanta, Georgia, United States of America

3. Geneva University Hospitals and Faculty of Medicine, WHO Collaborating Centre on

$$
\text { Patient Safety, Geneva, Switzerland }
$$

4. King Abdulaziz Medical City, WHO Collaborating Centre for Infection Prevention and Control and Anti-Microbial, Riyadh, Saudi Arabia

5. Technical University of Denmark, National Food Institute, WHO Collaborating Centre for Antimicrobial Resistance in Foodborne Pathogens and Genomics, Kongens Lyngby, Denmark

6. College of Veterinary Medicine, North Carolina State University, WHO Collaborating Centre for Global One Health and Antimicrobial Resistance Initiatives, Raleigh, North 
medRxiv preprint doi: https://doi.org/10.1101/2021.03.24.21253807; this version posted March 26, 2021. The copyright holder for this preprint (which was not certified by peer review) is the author/funder, who has granted medRxiv a license to display the preprint in

All rights reserved. No reuse allowed without permission.

25 7. Public Health Agency of Sweden, WHO Collaborating Centre for Antimicrobial Resistance

26 Containment, Stockholm, Sweden

27 8. National Institute for Communicable Diseases and School of Pathology at University of

28 Witwatersrand, WHO Collaborating Centre for Antimicrobial Resistance, Johannesburg,

29 South Africa

30 9. National Infection Service Laboratories, Public Health England, WHO Collaborating

31 Centre for Reference \& Research on Antimicrobial Resistance and Healthcare Associated

32 Infections, London, United Kingdom

33 10. Brigham and Women's Hospital, WHO Collaborating Centre for Surveillance of

34 Antimicrobial Resistance, Boston, Massachusetts, United States of America

35 11. Surveillance, Prevention and Control Department, World Health Organization, Geneva,

$36 \quad$ Switzerland

37

38 *Corresponding author: Tomczyks@rki.de, +49 30187542748

39 Short running title: Impact of COVID-19 on Antimicrobial Resistance (AMR) 
medRxiv preprint doi: https://doi.org/10.1101/2021.03.24.21253807; this version posted March 26, 2021. The copyright holder for this preprint (which was not certified by peer review) is the author/funder, who has granted medRxiv a license to display the preprint in All rights reserved. No reuse allowed without permission.

Synopsis (250 words)

\section{Objectives}

44 The COVID-19 pandemic has had a substantial impact on health systems. The WHO

Antimicrobial Resistance (AMR) Collaborating Centres Network conducted a survey to assess the effects of COVID-19 on AMR surveillance, prevention and control.

\section{Methods}

From October-December 2020, WHO Global Antimicrobial Resistance and Use Surveillance

System (GLASS) national focal points completed a questionnaire including Likert-scales and open-ended questions. Data were descriptively analysed, income/regional differences were assessed, and free-text questions were thematically analysed.

\section{Results}

Seventy-three countries across income levels participated. During the COVID-19 pandemic,

$67 \%$ reported limited ability to work with AMR partnerships; decreases in funding were availability of nursing, medical and public health staff for AMR was reported by $71 \%, 69 \%$ and $64 \%$, respectively, whereas $67 \%$ reported stable cleaning staff availability. The majority $(58 \%)$ reported reduced reagents/consumables, particularly LMICs $(p<0.01)$. Decreased

61 numbers of cultures, elective procedures, chronically ill admissions and outpatients and

62 increased intensive care unit admissions reported could bias AMR data. Reported overall

63 infection prevention and control (IPC) improvement could decrease AMR rates, whereas 
medRxiv preprint doi: https://doi.org/10.1101/2021.03.24.21253807; this version posted March 26, 2021. The copyright holder for this preprint (which was not certified by peer review) is the author/funder, who has granted medRxiv a license to display the preprint in All rights reserved. No reuse allowed without permission.

64 increases in selected inappropriate IPC practices and antibiotic prescribing could increase

65 rates. Most did not yet have complete data on changing AMR rates due to COVID-19.

66

\section{Conclusions}

68 This was the first survey to explore the global impact of COVID-19 on AMR among GLASS

69 countries. Responses revealed universal patterns but also captured country variability.

70 Although focus is understandably on COVID-19, gains in detecting and controlling AMR, a

71 global health priority, cannot afford to be lost. 
medRxiv preprint doi: https://doi.org/10.1101/2021.03.24.21253807; this version posted March 26, 2021. The copyright holder for this preprint (which was not certified by peer review) is the author/funder, who has granted medRxiv a license to display the preprint in All rights reserved. No reuse allowed without permission.

\section{Introduction}

The coronavirus disease 2019 (COVID-19) pandemic has had a substantial impact on health systems globally, affecting the management of other health threats such as antimicrobial resistance (AMR). The World Health Organization (WHO) declared that AMR is one of the top ten global health threats and, although often more silent than the COVID-19 pandemic, it can have equally devastating consequences. ${ }^{1}$ From 2017-2019, the number of countries reporting AMR rates to WHO's Global Antimicrobial Resistance and Use Surveillance System (GLASS) exponentially grew from 729 in 22 countries to more than 64,000 in 66 countries. ${ }^{2}$ However, the effects of the COVID-19 pandemic threatens the progress made and is thought to be having wide-reaching impacts on AMR surveillance, prevention and control efforts. Experts have highlighted the link between COVID-19 and AMR, indicating that certain changes such as increased antibiotic use could drive an increase in AMR; while other activities such as improved infection prevention and control (IPC) might reduce AMR rates..$^{3-6}$ This underlines the importance of maintaining AMR surveillance to monitor trends during the COVID-19 pandemic.

The WHO AMR Surveillance and Quality Assessment Collaborating Centres Network is a global network of institutes with expertise in AMR, health care-associated infections, and antimicrobial consumption. It aims to support WHO's efforts to combat AMR through the development and implementation of AMR surveillance and related activities. ${ }^{7}$ We conducted a survey among countries enrolled in GLASS to assess the global effects of COVID-19 on AMR surveillance, prevention and control, focusing on challenges as well as opportunities.

\section{Materials and methods}


medRxiv preprint doi: https://doi.org/10.1101/2021.03.24.21253807; this version posted March 26, 2021. The copyright holder for this preprint (which was not certified by peer review) is the author/funder, who has granted medRxiv a license to display the preprint in All rights reserved. No reuse allowed without permission. response.

A structured questionnaire was developed with expert input from Network members

(Supplementary data). The WHO health system building blocks framework was considered to ensure that the impacts of COVID-19 on different health system areas were comprehensively addressed. ${ }^{8}$ Accordingly, the questionnaire consisted of compulsory Likert-scale questions to assess the impacts of COVID-19 in ten topic areas (i.e. 2-10 questions per topic area): Funding for AMR activities; Partnerships and oversight for AMR activities; Diagnostics and laboratory testing for AMR; Laboratory supplies and equipment for AMR activities; Availability of staff for AMR activities; AMR data information systems; Patient-case mix; IPC practices; Antibiotic consumption; and AMR rates (Supplementary data). Likert-scale responses included "Large decrease", "Moderate decrease", "No impact", "Moderate increase", "Large increase", and "Do not know." To further explore country experiences, each topic area ended with an optional open-ended question and three optional openended questions were included at the end of the questionnaire. Upon approval from the data protection office of the Network coordinator (Robert Koch Institute, Berlin, Germany), the questionnaire was programmed using the online Voxco survey software including validity and completeness checks.

From October-December 2020, the questionnaire link was sent to the national focal points of all countries enrolled in GLASS. Each GLASS national focal point was asked to consider input from their relevant country experts (e.g. epidemiology, clinical, laboratory, IPC) and submit one compiled response per country. There was active follow-up with reminders, and countries which submitted more than one response were requested to indicate their final 
medRxiv preprint doi: https://doi.org/10.1101/2021.03.24.21253807; this version posted March 26, 2021. The copyright holder for this preprint (which was not certified by peer review) is the author/funder, who has granted medRxiv a license to display the preprint in All rights reserved. No reuse allowed without permission.

120 The data collected were descriptively analysed using the statistical programme R (version

121 4.0.3). Completed Likert-scale responses were graphically displayed for each of the ten topic

122 areas. Differences in responses between countries according to WHO regions and World

123 Bank income levels ${ }^{9}$ were assessed using the Fisher's exact test and significant differences

$124(p<0.05)$ were reported. Free-text questions were reviewed to identify specific themes,

125 coded accordingly and considered in relation to the corresponding topic area Likert-scale

126 findings (Supplementary data). If minor typographical errors were corrected in quotations

127 for comprehension, this was indicated with "sic".

128

\section{Results}

130 A total of 73 countries responded to the survey, corresponding to $75 \%$ of countries enrolled

131 in GLASS at the time of the survey (Table 1). The regional and income distribution of survey

132 respondents was similar to those in GLASS, including 16\% (12/73) low-income, $23 \%(17 / 73)$

133 lower middle-income, 21\% (15/73) upper middle-income and 37\% (27/73) high-income

134 countries (Table 1). The median number of countries providing a response for each

135 mandatory question was 66 (i.e. incompleteness included selection of "Do not know").

137 Funding for AMR activities

138 Among those that responded, less than half of countries reported decreases in funding for

139 AMR activities at the national $(29 / 70 ; 41 \%)$ or local/facility level (30/69; 43\%) (Figure 1a).

140 Decreases in national and local funding were reported more frequently by low- $(9 / 10 ; 9 / 10)$

141 and middle-income $(15 / 30 ; 16 / 30)$ countries compared to high-income $(3 / 27 ; 3 / 26)$

142 countries, respectively $(p<0.01)$. Decreases were also more frequently reported by the

143 African and Eastern Mediterranean regions compared to other regions $(p<0.01)$. In the free- 
medRxiv preprint doi: https://doi.org/10.1101/2021.03.24.21253807; this version posted March 26, 2021. The copyright holder for this preprint (which was not certified by peer review) is the author/funder, who has granted medRxiv a license to display the preprint in All rights reserved. No reuse allowed without permission.

144 text questions (Table 2), various countries reported that funding was prioritized for COVID-

14519 over AMR. This ranged from selected low-income countries who reported being

146 dependent on external funding for AMR that was impacted by COVID-19 to high-income

147 countries that reported more indirect effects which reduced resources for AMR activities. In

148 contrast, one middle-income country reported that the COVID-19 pandemic allowed them to

149 secure additional AMR funding, and another was able to purchase resources for overall IPC

150 with COVID-19 funds.

151

152 Partnerships and oversight for AMR activities

153 More than half of responding countries reported decreases in their ability to work with new

$154(44 / 73 ; 60 \%)$ or existing $(48 / 72 ; 67 \%)$ partnerships, as well as in the ability of the national

155 AMR coordinating body to have oversight of activities (44/70; 63\%) (Figure 1b). In contrast,

156 eleven $(11 / 73 ; 15 \%)$ countries reported increases in the ability to create new partnerships

157 since the COVID-19 pandemic. No significant income level or regional differences were seen.

158 In the free-text questions (Table 2), a few low- and middle-income countries (LMICs)

159 reported compounding challenges affecting partnerships, such as mobility restrictions and

160 poor internet connections. Selected middle- and high-income countries described

161 opportunities such as the creation of new partnership platforms, possibilities for data

162 exchange, and identified gaps relevant for both COVID-19 and AMR action-planning.

\section{Diagnostics and laboratory testing for AMR}

165 A majority of countries responding reported decreases in the number of screening (65\%;

$16644 / 68)$ and clinical (67\%; 46/69) cultures requested (Figure 1c). Although more than half of

167 countries $(42 / 70 ; 60 \%)$ reported no impact on the turn-around time of antimicrobial 
medRxiv preprint doi: https://doi.org/10.1101/2021.03.24.21253807; this version posted March 26, 2021. The copyright holder for this preprint (which was not certified by peer review) is the author/funder, who has granted medRxiv a license to display the preprint in All rights reserved. No reuse allowed without permission.

168 susceptibility results (AST), many (48/69; 70\%) reported decreases in their ability to provide

169 training for laboratory personnel; 46\% (27/59) and 43\% (29/68) also reported decreases in

170 the ability to carry out molecular testing and quality management activities, respectively. No

171 significant income level or regional differences were seen. In the free-text questions (Table

172 2), countries across income levels described influencing factors such as fewer patients

173 visiting hospitals and the need to divert staff, equipment and reagents for COVID-19 testing.

174 In contrast, one low-middle-income country reported that the laboratory network was

175 strengthened in their country and expected this to have a positive impact on the response

176 against AMR. Selected countries across income levels also highlighted the potential for

177 leveraging COVID-19 work for AMR, such as in the area of microbial genomics and rapid

178 testing for co-infections or secondary bacterial infections.

Laboratory supplies and equipment for AMR activities

181 More than half of responding countries reported decreases in the availability of quality

182 laboratory reagents and consumables for bacteriology and AST $(41 / 71 ; 58 \%)$ and in the

183 ability to service machines and equipment (35/67; 52\%) (Figure 1d). In contrast, 41\% ( $n=29)$

184 and $50 \%(n=33)$ of countries reported no impact on reagent/consumable availability and

185 access to advanced technologies, respectively. Decreases in reagent/consumable availability

186 were reported more frequently by low- (11/11) and middle-income (17/31) countries

187 compared to high-income $(11 / 26)$ countries, respectively $(p<0.01)$. Decreases were also

188 more frequently reported by the African and Eastern Mediterranean regions compared to

189 other regions ( $p<0.01)$. In the free-text questions (Table 2 ), countries reported broad

190 difficulties receiving supplies due to travel and import restrictions. High-income countries 
medRxiv preprint doi: https://doi.org/10.1101/2021.03.24.21253807; this version posted March 26, 2021. The copyright holder for this preprint (which was not certified by peer review) is the author/funder, who has granted medRxiv a license to display the preprint in All rights reserved. No reuse allowed without permission.

191 reported more specific impacts on particular supplies due to COVID-19 testing, such as the

192 availability of molecular diagnostic platforms.

193

194 Availability of staff responsible for AMR activities

195 Responding countries reported the largest decreases in the availability of nursing (48/68;

$19671 \%)$, medical $(47 / 68 ; 69 \%)$ and public health staff $(43 / 67 ; 64 \%)$ for AMR activities such as

197 stewardship, outbreak response and reporting (Figure 1e). In contrast, $67 \%$ of countries

$198(45 / 67)$ reported no impact or increases in the availability of environmental cleaning

199 workers. Increases in the availability of IPC focal points were reported by $56 \%(38 / 68)$ and

200 more frequently by low- (4/11) and middle-income (5/32) countries compared to high-

201 income $(0 / 22)$ countries $(p=0.03)$. In the free-text questions (Table 2$)$, many countries across

202 income levels described significant public health, medical, nursing and laboratory workforce

203 challenges. One high-income country stated that there had been a reduction in staff due to

204 closed borders. Selected countries across income levels highlighted the importance of

205 aligning COVID-19 and AMR staff trainings. One middle-income country requested increased

206 virtual communication between GLASS national focal points on AMR in the context of

207 COVID-19.

208

209 AMR data information systems

210 Most countries who responded reported no impact on clinical $(53 / 67 ; 79 \%)$ or laboratory

211 (56/72; 78\%) data information systems for AMR (Figure 1f). No significant income level or

212 regional differences. In the free-text questions (Table 2), one low-income country reported

213 decreases in the use of AMR data information systems during the pandemic, whereas one 
medRxiv preprint doi: https://doi.org/10.1101/2021.03.24.21253807; this version posted March 26, 2021. The copyright holder for this preprint (which was not certified by peer review) is the author/funder, who has granted medRxiv a license to display the preprint in All rights reserved. No reuse allowed without permission.

214 high-income country highlighted potential opportunities for integrating AMR and SARS-CoV-

2152 data.

Patient-case mix

218 Most responding countries reported decreases in the number of elective surgical procedures 219 (60/66; 91\%), outpatient visits (53/68; 78\%) and chronically ill inpatient admissions (42/64;

$22066 \%$ ), while more than half of countries reported increases in intensive care unit (ICU)

221 admissions $(38 / 67 ; 57 \%)$ and the occupancy rate of ICU beds $(41 / 63 ; 65 \%)$ (Figure $1 \mathrm{~g})$.

222 Decreases in outpatient visits were reported more frequently by high- $(21 / 24)$ and middle-

223 income (24/30) countries compared to low-income $(6 / 11)$ countries $(p=0.04)$. In the free-text

224 questions (Table 2), countries across income levels reported changes due to the

225 reorganisation of healthcare services such as hospitals prioritising only COVID-19 patients,

226 reducing non-emergency services, and diversion to online or phone consultations. A small

227 number of LMICs reported the closure of primary health care facilities for several months as

228 well as the perception that patients were avoiding all health care facilities during the

229 pandemic.

IPC practices

232 Many responding countries reported improvements in IPC as a result of COVID-19. This

233 included a majority reporting increases in hand hygiene compliance (53/66; 80\%), availability

234 of alcohol-based hand rub (54/69; 78\%), availability of personal protective equipment (PPE;

$23550 / 69 ; 72 \%)$, and ability to carry out IPC training (47/66; 71\%) (Figure 1h). More than half of

236 countries reported no impact on the ability to cohort patients by multidrug-resistant

237 organism status (33/55, 60\%). In contrast, $45 \%$ (27/60) of countries reported an increase in 
medRxiv preprint doi: https://doi.org/10.1101/2021.03.24.21253807; this version posted March 26, 2021. The copyright holder for this preprint (which was not certified by peer review) is the author/funder, who has granted medRxiv a license to display the preprint in All rights reserved. No reuse allowed without permission.

238 inappropriate IPC practices such as double gowning or gloving and performing hand hygiene

239 over gloved hands. No significant income level or regional differences were seen. In the free-

240 text questions (Table 2), countries of all income levels highlighted the strengthening of IPC

241 efforts through awareness campaigns and training. However, one middle-income country

242 reported social distancing and poor internet connection as barriers to delivering training and

243 one high-income country reported the use of peers and link nurses for training due to

244 overworked IPC staff. Several middle-and high-income countries also highlighted IPC lessons

245 learned from COVID-19 such as the need to better integrate IPC across the entire healthcare

246 delivery system and the need for earlier focus on IPC implementation in long-term care

247 facilities.

\section{Antibiotic consumption}

250 More than half of responding countries (35/56; 63\%) reported increases in total prescribing

251 of antibiotics (Figure 1i). More specifically, 47\% (23/49), 57\% (27/47) and 40\% (18/45) of

252 countries reported increased use of WHO Access, Watch, and Reserve antibiotics,

253 respectively. More than half of countries $(33 / 58 ; 57 \%)$ reported no impact on the availability

254 of antibiotics. Increases in total prescribing were reported more frequently by low- $(8 / 10)$

255 and middle-income (18/24) countries compared to high-income $(7 / 20)$ countries $(p=0.03)$. In

256 the free-text questions (Table 2), countries across income levels highlighted preliminary data

257 suggesting increases in antibiotic use although many were also not yet able to assess.

258 Selected high-income countries specified increases in the use of watch and reserve

259 antibiotics such as azithromycin at health care facilities. One middle-income country

260 reported that antibiotics are being prescribed in almost all cases of COVID-19 regardless of

261 indications and one low-income country reported that more people in the community were 
medRxiv preprint doi: https://doi.org/10.1101/2021.03.24.21253807; this version posted March 26, 2021. The copyright holder for this preprint (which was not certified by peer review) is the author/funder, who has granted medRxiv a license to display the preprint in All rights reserved. No reuse allowed without permission.

262 self-prescribing antibiotics. In contrast, a few middle- and high-income countries reported

263 reductions in levels of prescribing due to less healthcare utilization.

AMR rates

266 Fewer countries were able to report on the impacts of COVID-19 on AMR rates. Among

267 those that responded, 37\% (13/35) and 40\% (12/30) of countries reported increases in multi-

268 drug resistant (MDR) healthcare-associated infections and MDR infections in long-term care

269 facilities, respectively (Figure 1j). Approximately one third of countries reported increases in

270 Gram negative organisms such as Klebsiella pneumoniae (15/42; 36\%), Acinetobacter spp.

271 (13/40; 32\%), and Escherichia coli (13/42; 31\%) and Gram-positive organisms such as

272 Staphylococcus aureus (24\%; 10/41) and Streptococcus pneumoniae (29\%; 11/38). No

273 impacts on selected organisms were reported more frequently by high- and middle-income

274 countries compared to low-income countries $(p<0.01)$. In the free-text questions (Table 2$)$,

275 many countries across income levels reported that they were not yet able to reliably report

276 on AMR data. Several high-income countries suggested that resistance rates may be higher

277 as a result of more patients being treated in ICUs or long-term care settings. A few LMICs

278 suggested that there may be a reduction in resistance due to fewer patients presenting to

279 the hospital overall.

282 In the free-text questions (Table 2), predictions from countries across income levels on the

283 long-term impacts of the pandemic on AMR were mixed, citing factors that could reduce

284 resistance, such as improved IPC, versus factors that could increase resistance, such as

285 worsening of antimicrobial stewardship practices, increased staff fatigue to detect AMR 
medRxiv preprint doi: https://doi.org/10.1101/2021.03.24.21253807; this version posted March 26, 2021. The copyright holder for this preprint (which was not certified by peer review) is the author/funder, who has granted medRxiv a license to display the preprint in All rights reserved. No reuse allowed without permission.

286 threats, and reduced prioritization of AMR initiatives in place of those on COVID-19. One

287 middle-income country suggested that the negative effects on AMR were greatest at the

288 start of the pandemic. Many countries across income levels highlighted the need to balance

289 COVID-19 and AMR response activities and address gaps in funding, staffing, consumables,

290 equipment and IT infrastructure. A few middle- and high-income countries suggested the

291 need to develop tools such as improved guidelines on antibiotic prescribing for COVID-19

292 patients and expanded rapid and molecular testing. A few countries across income levels

293 emphasized the importance of continued health system strengthening and resiliency

294 including IPC and AMR awareness.

295

\section{Discussion}

297 The COVID-19 pandemic is having wide-reaching impacts on all aspects of our health

298 systems. These have upended various levels of AMR surveillance, prevention and control.

299 Including a wide range of country settings, this survey gives an important initial picture of

300 the global impacts that COVID-19 has on these AMR aspects. Responses from GLASS national

301 focal points revealed some universal patterns but also captured the variability across

302 countries which, in some cases, could be linked to income level. The reported impacts

303 involved factors that could bias AMR reporting as well as potentially decrease or increase

304 AMR rates. These findings provide a useful framework to inform the ongoing

305 implementation of AMR surveillance and interpretation of data. They also present key

306 country insights on how we might use the COVID-19 response to make continued gains in 307 combatting AMR. 
medRxiv preprint doi: https://doi.org/10.1101/2021.03.24.21253807; this version posted March 26, 2021. The copyright holder for this preprint (which was not certified by peer review) is the author/funder, who has granted medRxiv a license to display the preprint in All rights reserved. No reuse allowed without permission.

309 Reported aspects which could bias AMR data included a range of changes in health care

310 utilisation, testing activities and diagnostic resources. These included decreases in the

311 number of cultures, elective surgeries, chronically ill admissions and outpatient visits

312 (particularly in LMICs) as well as increases in ICU admissions. Other observational and quasi-

313 experimental studies have similarly documented reductions in global surgical case volume

314 proxies as well as hospital emergency department visits particularly in high-income

315 countries. ${ }^{10-12}$ Such changes in patients and testing denominators should be considered

316 where feasible when interpreting changes in AMR data and potential biases.

Many countries reported IPC improvements which could favour the prevention of both AMR and COVID-19, such as hand hygiene, PPE use, the stable availability of environmental

320 cleaning workers and increased availability of IPC focal points (particularly in LMICs). WHO

321 has highlighted the importance of effective COVID-19 IPC measures including compliance

322 with standard and transmission-based precautions, ${ }^{13}$ and many countries and facilities seem

323 to be taking steps to promote this guidance. Improved IPC awareness and implementation

324 has been shown to improve after large outbreaks, as also seen after the 2014/2016 Ebola

325 outbreak. ${ }^{14}$ It is an opportunity that can be utilised to promote sustainable IPC programmes

326 that can more effectively combat emerging threats such as COVID-19 and Ebola as well as

327 AMR transmission.

329 Increased total antibiotic prescribing was reported by more than half of countries,

330 particularly by LMICs. Specific increases in WHO Watch antibiotics (e.g. azithromycin) were 331 also seen despite conflicting evidence for COVID-19 patients. ${ }^{15}$ Meta-analyses by Langford et 332 al. and Rawson et al. found that approximately three quarters of hospitalized COVID-19 
medRxiv preprint doi: https://doi.org/10.1101/2021.03.24.21253807; this version posted March 26, 2021. The copyright holder for this preprint (which was not certified by peer review) is the author/funder, who has granted medRxiv a license to display the preprint in All rights reserved. No reuse allowed without permission.

333 patients received antibiotics, although 3.5\% and $8.5 \%$ were estimated to have bacterial co-

334 infections on presentation and bacterial/fungal co-infections during admission,

335 respectively. ${ }^{16,17}$ Hospital-based studies have shown significant increases in total antibiotic

336 use, including broad-spectrum antibiotic use such as cefepime, piperacillin/tazobactam and

337 carbapenems. ${ }^{18-20}$ National outpatient studies have found both decreases in antibiotic

338 prescriptions due to COVID-19 restrictions ${ }^{21,22}$ and increases in expected prescriptions after

339 controlling for changes in the number of telephone consultations versus in-person

340 appointments. ${ }^{23}$ In light of these results, evidence-based guidelines such as the indications

341 for antibacterial therapy in COVID-19 patients should be promoted globally to prevent the

342 accelerated threat of AMR. ${ }^{24-26}$

344 Although improved IPC efforts should be leveraged for both COVID-19 and AMR, an overly

345 simplistic approach should also be avoided. Not all IPC measures for respiratory disease will

346 be effective against AMR transmission. Inappropriate IPC practices (e.g. double gloving)

347 reported by half of countries in this survey should be avoided. Other studies have also

348 reported the unintended consequences of inappropriate PPE practices during the COVID-19

349 and SARS outbreaks, leading to higher risks of contamination. ${ }^{27-29}$

351 Various programmatic and structural factors which could reduce AMR activities were also

352 reported by countries. Decreases in the routine ability to work with partnerships, funding,

353 staffing and supplies could lead to important gaps in communication, implementation and

354 data exchange. Specific challenges related to border closures, blocked imports and

355 competition for limited stocks of material leading to disparities across countries have been

356 highlighted in other anecdotal reports. ${ }^{3-6,30,31}$ Despite these challenges, some countries 
medRxiv preprint doi: https://doi.org/10.1101/2021.03.24.21253807; this version posted March 26, 2021. The copyright holder for this preprint (which was not certified by peer review) is the author/funder, who has granted medRxiv a license to display the preprint in All rights reserved. No reuse allowed without permission.

357 reported efforts to identify areas where the COVID-19 and AMR responses overlap (e.g.

358 integrated stewardship guidance, new partnership platforms, leverage of funding for health

359 systems strengthening and overall laboratory network improvements). These strategies are

360 critical to maintaining routine AMR control alongside the COVID-19 response. It is equally

361 important to recognise where response activities are not the same and additional efforts are

362 needed, such as investments in staffing and back-up suppliers.

364 Most countries did not yet have complete data on AMR rates. It is still early in the course of

365 the pandemic to reliably report on any changes. Although it will take time to effectively

366 analyse these data, reported factors such as decreases in surveillance capacity could limit

367 the ability to provide data on true AMR changes. It is critical that AMR activities remain a

368 priority for countries and high on the global health agenda to ensure the necessary capacity

369 to detect and respond to emerging threats. Outbreaks and increases in AMR acquisition,

370 such as carbapenemase-producing Enterobacterales, during the COVID-19 pandemic have

371 been reported by hospitals, demonstrating the importance of continuing routine AMR

372 activities and closely monitoring these data. ${ }^{19,}$ 32-35

373

374 Several survey limitations should be considered. Although these results provide a useful

375 initial global snapshot of the impacts of COVID-19 on AMR, they could also be considered an

376 oversimplification of complex and varying experiences across national and facility levels.

377 Heterogeneity between countries in the robustness of their existing AMR surveillance

378 systems and activities (i.e. capacity, experience, resources) may have affected survey

379 interpretation. If national focal points did not coordinate their responses with other experts

380 or did not have sufficient knowledge of the data or dynamics in their country, the validity 
medRxiv preprint doi: https://doi.org/10.1101/2021.03.24.21253807; this version posted March 26, 2021. The copyright holder for this preprint (which was not certified by peer review) is the author/funder, who has granted medRxiv a license to display the preprint in All rights reserved. No reuse allowed without permission.

381 and reliability of some responses may have been affected. Furthermore, self-reported

382 perceptions of national focal points on the impacts of COVID-19 on AMR could have also

383 been affected by self-desirability bias.

385 This survey was the first concerted effort to explore the global impact of COVID-19 on AMR

386 surveillance, prevention and control among GLASS countries. Although much focus is

387 understandably placed on COVID-19 at present, we believe that AMR must remain high on

388 the global health agenda. This survey included a wide range of country settings and

389 responses which highlighted both the universal effects of COVID-19 on AMR as well as the

390 heterogeneity of impacts across countries. The results underscore the importance of finding

391 ways to leverage the COVID-19 response activities to also support routine AMR prevention

392 and control, where possible, and advocate for continued investments in IPC and laboratory

393 strengthening for overall health system preparedness. It is critical to continue to monitor the

394 dynamic situation and update national action plans with lessons learned to include

395 preparedness and mitigation for future emerging threats that may also affect routine AMR

396 work. Countries are encouraged to engage with GLASS and the Network to work collectively

397 towards leveraging opportunities and addressing present challenges to improve AMR

398 surveillance, prevention and control.

400 Acknowledgements

401 We would like to acknowledge all of the WHO Collaborating Centres that are part of the

402 WHO AMR Surveillance and Quality Assessment Collaborating Centres Network:

403 https://www.who.int/glass/collaborating-centres-network/en/. In addition, we would like to

404 acknowledge Muna Abu Sin and Birgitta Schweickert (Robert Koch Institute, Berlin, 
medRxiv preprint doi: https://doi.org/10.1101/2021.03.24.21253807; this version posted March 26, 2021. The copyright holder for this preprint (which was not certified by peer review) is the author/funder, who has granted medRxiv a license to display the preprint in All rights reserved. No reuse allowed without permission.

405 Germany) who provided feedback on the questionnaire structure. We would like to sincerely

406 thank all of the participating countries enrolled in GLASS at the time of the survey. Those

407 that agreed to be acknowledged included: Afghanistan, Argentina, Australia, Bahrain, Bosnia

408 and Herzegovina, Croatia, Djibouti, Finland, France, Gabon, Gambia, Georgia, Germany,

409 Greece, India, Indonesia, Iraq, Ireland, Japan, Kenya, Lebanon, Liberia, Lithuania,

410 Madagascar, Mali, Morocco, Namibia, Netherlands, Oman, Pakistan, Palestine, Poland,

411 Qatar, Russian Federation, Singapore, South Africa, Sudan, Switzerland, Syrian Arab

412 Republic, Thailand, Trinidad and Tobago, Tunisia, Uganda, United Arab Emirates, United

413 Republic of Tanzania, United States of America, and Zambia.

\section{$415 \quad$ Funding}

416 This work was supported by a working group belonging to the WHO AMR Surveillance and

417 Quality Assessment Collaborating Centres Network. It was led by the coordinator of the

418 Network at the Robert Koch Institute in Berlin, Germany, who received funding from the

419 Global Protection Programme (GHPP) at the German Federal Ministry of Health.

420 Transparency

$421 \quad$ None to declare.

\section{Disclaimer}

423 The findings and conclusions in this report are those of the authors and do not necessarily

424 represent the official positions of their affiliated institutions.

\section{Supplementary data}

427 Supplementary Materials are available at the end of this manuscript. 
medRxiv preprint doi: https://doi.org/10.1101/2021.03.24.21253807; this version posted March 26, 2021. The copyright holder for this preprint (which was not certified by peer review) is the author/funder, who has granted medRxiv a license to display the preprint in All rights reserved. No reuse allowed without permission.

\section{References}

$430 \quad$ 1. World Health Organization. Global Action Plan on Antimicrobial Resistance.

431 https://www.who.int/antimicrobial-resistance/global-action-plan/en/.

432 2. World Health Organization. Record number of countries contribute data revealing disturbing

433 rates of antimicrobial resistance. https://www.who.int/news/item/01-06-2020-record-number-of-

434 countries-contribute-data-revealing-disturbing-rates-of-antimicrobial-resistance.

435 3. Getahun H, Smith I, Trivedi K et al. Tackling antimicrobial resistance in the COVID-19

436 pandemic. Bull World Health Organ 2020; 98: 442-a.

437 4. Donà D, Di Chiara C, Sharland M. Multi-drug-resistant infections in the COVID-19 era: a

438 framework for considering the potential impact. J Hosp Infect 2020; 106: 198-9.

439 5. Monnet DL, Harbarth S. Will coronavirus disease (COVID-19) have an impact on antimicrobial 440 resistance? Euro Surveill 2020; 25: 2001886.

441 6. Chibabhai V, Duse AG, Perovic O et al. Collateral damage of the COVID-19 pandemic:

442 Exacerbation of antimicrobial resistance and disruptions to antimicrobial stewardship programmes? $S$

443 Afr Med J 2020; 110: 572-3.

444 7. World Health Organization. WHO AMR Surveillance and Quality Assessment Collaborating

445 Centres Network. https://www.who.int/glass/collaborating-centres-network/en/.

$446 \quad$ 8. World Health Organization. Monitoring the building blocks of health systems.

447 https://www.who.int/healthinfo/systems/WHO_MBHSS_2010_full_web.pdf?ua=1.

448 9. World Bank. The world by income. https://datatopics.worldbank.org/world-development-

449 indicators/the-world-by-income-and-region.html.

450 10. O'Reilly-Shah VN, Van Cleve W, Long DR et al. Impact of COVID-19 response on global surgical

451 volumes: an ongoing observational study. Bull World Health Organ 2020; 98: 671-82.

452 11. Mulholland RH, Wood R, Stagg HR et al. Impact of COVID-19 on accident and emergency

453 attendances and emergency and planned hospital admissions in Scotland: an interrupted time-series analysis. J R Soc Med 2020; 113: 444-53. 
medRxiv preprint doi: https://doi.org/10.1101/2021.03.24.21253807; this version posted March 26, 2021. The copyright holder for this preprint (which was not certified by peer review) is the author/funder, who has granted medRxiv a license to display the preprint in All rights reserved. No reuse allowed without permission.

455 12. Sokolski M, Gajewski P, Zymliński R et al. Impact of Coronavirus Disease 2019 (COVID-19)

456 Outbreak on Acute Admissions at the Emergency and Cardiology Departments Across Europe. Am J

457 Med.

458 13. World Health Organization. Infection prevention and control during health care when

459 coronavirus disease (COVID-19) is suspected or confirmed.

460 https://www.who.int/publications/i/item/WHO-2019-nCoV-IPC-2020.4.

461 14. Tremblay N, Musa E, Cooper C et al. Infection prevention and control in health facilities in 462 post-Ebola Liberia: don't forget the private sector! Public Health Action 2017; 7: S94-s9.

463 15. Verdejo C, Vergara-Merino L, Meza N et al. Macrolides for the treatment of COVID-19: a

464 living, systematic review. Medwave 2020; 20: e8074.

465 16. Langford BJ, So M, Raybardhan S et al. Antibiotic prescribing in patients with COVID-19: rapid 466 review and meta-analysis. Clin Microbiol Infect.

467 17. Rawson TM, Moore LSP, Zhu N et al. Bacterial and Fungal Coinfection in Individuals With 468 Coronavirus: A Rapid Review To Support COVID-19 Antimicrobial Prescribing. Clin Infect Dis 2020.

469 18. Abelenda-Alonso G, Padullés A, Rombauts A et al. Antibiotic prescription during the COVID-

47019 pandemic: A biphasic pattern. Infect Control Hosp Epidemiol 2020; 41: 1371-2.

471 19. Bork JT, Leekha S, Claeys K et al. Change in hospital antibiotic use and acquisition of 472 multidrug-resistant gram-negative organisms after the onset of coronavirus disease 2019. Infect 473 Control Hosp Epidemiol 2020: 1-3.

474 20. Gonzalez-Zorn B. Antibiotic use in the COVID-19 crisis in Spain. Clin Microbiol Infect.

475 21. King LM, Lovegrove MC, Shehab $\mathrm{N}$ et al. Trends in U.S. outpatient antibiotic prescriptions 476 during the COVID-19 pandemic. Clin Infect Dis 2020.

477 22. Orubu ESF, Malik F, Figueras A et al. Antibacterial consumption in the context of COVID-19 in 478 Pakistan: an analysis of national pharmaceutical sales data for 2019-20. medRxiv 2020:

$479 \quad 2020.12 .05 .20244657$.

480 23. Armitage R, Nellums LB. Antibiotic prescribing in general practice during COVID-19. Lancet 481 Infect Dis. 
medRxiv preprint doi: https://doi.org/10.1101/2021.03.24.21253807; this version posted March 26, 2021. The copyright holder for this preprint (which was not certified by peer review) is the author/funder, who has granted medRxiv a license to display the preprint in All rights reserved. No reuse allowed without permission.

482 24. Sieswerda E, de Boer MGJ, Bonten MMJ et al. Recommendations for antibacterial therapy in

483 adults with COVID-19 - an evidence based guideline. Clin Microbiol Infect 2021; 27: 61-6.

484 25. National Institute for Health and Care Excellence (UK). COVID-19 rapid guideline: antibiotics

485 for pneumonia in adults in hospital. https://www.ncbi.nlm.nih.gov/books/NBK566162/.

486 26. World Health Organization. COVID-19 Clinical management: living guidance.

487 https://www.who.int/publications/i/item/WHO-2019-nCoV-clinical-2021-1.

488 27. Yap FHY, Gomersall CD, Fung KSC et al. Increase in Methicillin-Resistant Staphylococcus 489 aureus Acquisition Rate and Change in Pathogen Pattern Associated with an Outbreak of Severe 490 Acute Respiratory Syndrome. Clin Infect Dis 2004; 39: 511-6.

491 28. Meda M, Gentry V, Reidy P et al. Unintended consequences of long-sleeved gowns in a 492 critical care setting during the COVID-19 pandemic. J Hosp Infect 2020; 106: 605-9.

493 29. Stevens MP, Doll M, Pryor R et al. Impact of COVID-19 on traditional healthcare-associated 494 infection prevention efforts. Infect Control Hosp Epidemiol 2020; 41: 946-7.

495 30. Hsu J. How covid-19 is accelerating the threat of antimicrobial resistance. Br Med J 2020; 496 369: m1983.

497 31. Lucien MAB, Canarie MF, Kilgore PE et al. Antibiotics and antimicrobial resistance in the 498 COVID-19 era: Perspective from resource-limited settings. Int J Infect Dis 2021; 104: 250-4.

499 32. Tiri B, Sensi E, Marsiliani V et al. Antimicrobial Stewardship Program, COVID-19, and Infection 500 Control: Spread of Carbapenem-Resistant Klebsiella Pneumoniae Colonization in ICU COVID-19 501 Patients. What Did Not Work? J Clin Med 2020; 9.

502 33. Cantón R, Akóva M, Carmeli Y et al. Rapid evolution and spread of carbapenemases among 503 Enterobacteriaceae in Europe. Clin Microbiol Infect 2012; 18: 413-31.

504 34. Farfour E, Lecuru M, Dortet L et al. Carbapenemase-producing Enterobacterales outbreak: 505 Another dark side of COVID-19. Am J Infect Control 2020; 48: 1533-6.

506 35. Gomez-Simmonds A, Annavajhala MK, McConville TH et al. Carbapenemase-producing 507 Enterobacterales causing secondary infections during the COVID-19 crisis at a New York City hospital. 
medRxiv preprint doi: https://doi.org/10.1101/2021.03.24.21253807; this version posted March 26, 2021. The copyright holder for this preprint (which was not certified by peer review) is the author/funder, who has granted medRxiv a license to display the preprint in

perpetuity.
All rights reserved. No reuse allowed without permission.

Table 1. Descriptive characteristics of survey respondents ("Survey"; $N=73$ ) compared to total countries participating in GLASS at the time of the survey ("GLASS"; N=98)

\begin{tabular}{|c|c|c|c|c|}
\hline \multirow{2}{*}{ Characteristic } & \multicolumn{2}{|c|}{ Survey } & \multicolumn{2}{c|}{ GLASS } \\
\cline { 2 - 5 } & $\mathbf{N}$ & $\%$ & $\mathbf{N}$ & $\%$ \\
\hline Income level & & & & \\
Low-income & 12 & $16.4 \%$ & 17 & $17.3 \%$ \\
Lower Middle-income & 17 & $23.3 \%$ & 27 & $27.6 \%$ \\
Upper Middle-income & 15 & $20.5 \%$ & 20 & $20.4 \%$ \\
High-income & 27 & $37.0 \%$ & 34 & $34.7 \%$ \\
Unknown* & 2 & $2.7 \%$ & & \\
\hline Total & 73 & - & 98 & - \\
Region & & & & \\
African Region (AFR) & 16 & $21.9 \%$ & 26 & $26.5 \%$ \\
Region of the Americas (AMR) & 5 & $6.8 \%$ & 6 & $6.1 \%$ \\
South-East Asia Region (SEAR) & 7 & $9.6 \%$ & 11 & $11.2 \%$ \\
European Region (EUR) & 20 & $27.4 \%$ & 25 & $25.5 \%$ \\
Eastern Mediterranean Region (EMR) & 18 & $24.7 \%$ & 21 & $21.4 \%$ \\
Western Pacific Region (WPR) & 5 & $6.8 \%$ & 9 & $9.2 \%$ \\
Unknown* & 2 & $2.7 \%$ & & \\
\hline Total & 73 & - & 98 & - \\
\hline
\end{tabular}

* Respondent chose not to provide their country name 


\section{Table 2. Selected free-text reports by countries according to topic area and income level}

\begin{tabular}{|c|c|c|}
\hline Topic & Income level & Selected illustrative quotations \\
\hline \multirow[t]{4}{*}{$\begin{array}{l}\text { Funding for } \\
\text { AMR } \\
\text { activities }\end{array}$} & Low & $\begin{array}{l}\text { "Previously, there was a small fund from the WHO country office, but during the COVID-19 pandemic, all funding and activities for AMR } \\
\text { stopped till now...During the last } 10 \text { months, all focus is on COVID-19 and there is no support for AMR by governments and non- } \\
\text { governmental organizations." }\end{array}$ \\
\hline & Lower-middle & $\begin{array}{l}\text { "AMR surveillance activities for national and local levels moderately decreased due to the large amount of funding allocated to laboratory } \\
\text { services and treatment for covid-19 patients." }\end{array}$ \\
\hline & Upper-middle & "There was no funding for AMR surveillance at the national level before the pandemic." \\
\hline & High & $\begin{array}{l}\text { "Indirectly, we may conclude that there is a decrease in AMR support as most microbiologists and epidemiologists were mobilized for } \\
\text { COVID diagnostics." }\end{array}$ \\
\hline \multirow{4}{*}{$\begin{array}{l}\text { Partnerships } \\
\text { and } \\
\text { oversight for } \\
\text { AMR } \\
\text { activities }\end{array}$} & Low & $\begin{array}{l}\text { "Due to the mobility restrictions, activities focused on AMR stopped. Sometimes, we try to use distanced calls but no success. Internet } \\
\text { connection is very limited in the country, it was difficult to reach each site [sic]." }\end{array}$ \\
\hline & Lower-middle & $\begin{array}{l}\text { "The WHO country office had requested a consultant to support our efforts to develop the AMR master plan, but due to the COVID-19 } \\
\text { outbreak, all those plans failed [sic]." } \\
\text { "COVID-19 has created platforms for new partnerships and collaborations because of the link in Infection Prevention interventions, e.g. } \\
\text { Water and Sanitation and Hygiene (WASH)." }\end{array}$ \\
\hline & Upper-middle & $\begin{array}{l}\text { "The COVID-19 pandemic crisis and the issuance of some strict measures to confront the Corona epidemic, including the imposition of a } \\
\text { complete curfew, led to poor communication with partners." }\end{array}$ \\
\hline & High & "More people and organisations have found each other, more possibilities regarding data exchange." \\
\hline \multirow{4}{*}{$\begin{array}{l}\text { Diagnostics } \\
\text { and } \\
\text { laboratory } \\
\text { testing for } \\
\text { AMR }\end{array}$} & Low & $\begin{array}{l}\text { "The schedules which had been made to train staff were stalled by the COVID-19 Pandemic. Laboratory turnaround time rose due to less } \\
\text { staff levels than usual on the microbiology benches [sic]." }\end{array}$ \\
\hline & Lower-middle & $\begin{array}{l}\text { "The laboratory network was strengthened in [our country] as part of the COVID-19 response and this will positively impact the AMR } \\
\text { surveillance network. The decision makers are now very sensitized to labs issues [sic]." }\end{array}$ \\
\hline & Upper-middle & $\begin{array}{l}\text { "Patients avoided visiting hospitals as they were afraid to be in close contact to the healthcare personnel and inpatients. This resulted in a } \\
\text { decrease of patient visits and microbiological orders [sic]." }\end{array}$ \\
\hline & High & $\begin{array}{l}\text { "Diagnostic pathology activity in microbiology laboratories... has declined when compared with the steep rise in testing work associated } \\
\text { with detection of SARS-COV-2." } \\
\text { "Whole genome sequencing (WGS) activity on antibiotic resistance strains has decreased because of the availability of WGS machines } \\
\text { (reserved for Covid), of molecular reagents and of staff (half team and staff rotation) [sic]." }\end{array}$ \\
\hline \multirow{3}{*}{$\begin{array}{l}\text { Laboratory } \\
\text { supplies and } \\
\text { equipment } \\
\text { for AMR } \\
\text { activities }\end{array}$} & Low & $\begin{array}{l}\text { "Because there has been a drop in samples being analysed and patients seen facilities, this has caused a reduction in the amount of } \\
\text { resources spent on supplies and consumables [sic]." }\end{array}$ \\
\hline & Lower-middle & $\begin{array}{l}\text { "There was no impact of COVID-19 on laboratory supplies and equipment for AMR activities as there was no functional surveillance during } \\
\text { the COVID-19 pandemic." }\end{array}$ \\
\hline & Upper-middle & "During Covid-19 lock out, we had many difficulties to import reagents, equipment and some parts in order to repair the equipment [sic]." \\
\hline
\end{tabular}




\begin{tabular}{|c|c|c|}
\hline & High & $\begin{array}{l}\text { "There was some impact on nucleic acid amplification-related work rather than standard culture and antimicrobial susceptibility testing. } \\
\text { Assays detecting resistance genes via nucleic acid amplification were in some cases delayed due to the availability of PCR platforms which } \\
\text { were in use mostly for SARS-COV-2 RNA detection." }\end{array}$ \\
\hline \multirow{4}{*}{$\begin{array}{l}\text { Availability } \\
\text { of staff } \\
\text { responsible } \\
\text { for AMR } \\
\text { activities }\end{array}$} & Low & $\begin{array}{l}\text { "Human resources has been one of the areas affected due to covid-19 responses, a lot of staff have been pulled to support covid-19 and } \\
\text { this leads to no activities and actions done." }\end{array}$ \\
\hline & Lower-middle & $\begin{array}{l}\text { "In general, most of health staff (doctors, nurses, lab staff, etc.) were called to respond activities of Covid-19 emergency, affecting the } \\
\text { availability of these professionals for AMR activities [sic]." }\end{array}$ \\
\hline & Upper-middle & $\begin{array}{l}\text { "We had a } 2 \text { [moderate impact] in the availability of health professionals in several places and a great increase in the need for professionals } \\
\text { during the beginning of the pandemic. Thus, the government supported the hiring of professionals through a specific program that } \\
\text { identified non-employed professionals, created a national register of professionals and local demand, and then allocated these } \\
\text { professionals where they were most needed." }\end{array}$ \\
\hline & High & $\begin{array}{l}\text { "Public health colleagues have been under enormous strain throughout } 2020 \text { dealing with the ongoing pandemic. In hospitals, particularly } \\
\text { those with small teams, the same core group of staff would traditionally deal with AMR response, stewardship and IPC activities and the } \\
\text { added demands of COVID-19 disproportionately affects the capacity of those teams to deal with AMR and stewardship. The increased focus } \\
\text { on environmental hygiene throughout the pandemic has likely impacted positively on cleaning. Laboratory scientific staffing resources are } \\
\text { already very stretched and the added demands of COVID-19 pandemic on staffing has made it even more challenging to recruit [sic]." }\end{array}$ \\
\hline \multirow{4}{*}{$\begin{array}{l}\text { AMR data } \\
\text { information } \\
\text { systems }\end{array}$} & Low & $\begin{array}{l}\text { "The biggest problem is that data are not generated as before and with the special focus on covid, dissemination platforms for data are not } \\
\text { available and people are not paying attention to other data sets, but only covid." }\end{array}$ \\
\hline & Lower-middle & "We have a National AMR database where AMR data are stored, so no changes were experienced [sic]." \\
\hline & Upper-middle & "Hospital administration initiated planning to prevent delayed reporting [sic]." \\
\hline & High & $\begin{array}{l}\text { "A laboratory-based surveillance system, originally implemented for AMR surveillance, was adapted to also capture data on SARS-CoV-2 } \\
\text { testing and allow for the analysis of co-infections [sic]." }\end{array}$ \\
\hline \multirow[t]{4}{*}{$\begin{array}{l}\text { Patient-case } \\
\text { mix }\end{array}$} & Low & $\begin{array}{l}\text { "Non-urgent hospital visits and elective surgeries decreased due to the COVID-19 scare... Hospital bed occupancy and intensive care unit } \\
\text { admission moderately increased due to COVID-19 positive cases being held for two weeks under observation. On the other end, chronically } \\
\text { ill cases were avoiding contact with the COVID-19 situations in the hospitals [sic]." }\end{array}$ \\
\hline & Lower-middle & $\begin{array}{l}\text { "Reduction or even stopping non-emergency hospital activities (non-urgent and elective surgical procedures) during confinement. Number } \\
\text { of ICU beds increased in some hospitals." }\end{array}$ \\
\hline & Upper-middle & $\begin{array}{l}\text { "We have reorganized health services. Some started to serve only COVID-19...In addition, the understanding at the beginning of the } \\
\text { pandemic that you should only k care in case of breathing difficulties generated a low demand for emergency care." }\end{array}$ \\
\hline & High & $\begin{array}{l}\text { "Preventive measures have been taken to reduce COVID-19 transmission such as the diversion to virtual clinics and phone consultation } \\
\text { mainly for outpatients, delivery of medicine to homes, reducing the stay in the hospital and discharging of the patients if the clinical } \\
\text { condition is ok, postponing the elective surgeries and working mainly on the emergency procedures and surgeries [sic]." }\end{array}$ \\
\hline \multirow{3}{*}{$\begin{array}{l}\text { Infection } \\
\text { prevention } \\
\text { and control } \\
\text { practices }\end{array}$} & Low & $\begin{array}{l}\text { "All people and at every work station were observing hand hygiene, social distancing, alcohol hand rub, and mask wearing which positively } \\
\text { controls spread of antimicrobial resistant organisms [sic]." }\end{array}$ \\
\hline & Lower-middle & "Our various hospital structures took advantage of this situation to strengthen their IPC activities (particularly awareness, training)." \\
\hline & Upper-middle & "Several campaigns have been held including WASH awareness campaigns." \\
\hline
\end{tabular}




\begin{tabular}{|c|c|c|}
\hline & & "Training is not possible due to strict social distancing. Virtual meetings are not practical if the IT system is not well supported [sic]." \\
\hline & High & $\begin{array}{l}\text { "IPC staff was overworked by COVID-19 and IPC training was performed by peers (by peers and IPC link nurses)." } \\
\text { "COVID-19 has revealed the need to integrate infection prevention and control across the entire healthcare delivery system. This needed } \\
\text { response includes strategies for implementation across all levels of care, use of data for targeted action, tailored tools and strategies for } \\
\text { early detection and management, effective ongoing communication and education, strong connection between public health and } \\
\text { healthcare, policies for accountability and sustainability, and an ongoing commitment to these improvements." }\end{array}$ \\
\hline \multirow[t]{4}{*}{$\begin{array}{l}\text { Antibiotic } \\
\text { consumption }\end{array}$} & Low & $\begin{array}{l}\text { "Due to the fever and other presenting symptoms of COVID-19, patients try to do self-medication and doctors also prescribe antibiotics } \\
\text { empirically since the infecting agent was not able to be cultured then." }\end{array}$ \\
\hline & Lower-middle & $\begin{array}{l}\text { "Consumption of WHO watch and reserve antibiotics increased because in rural facilities where diagnostic tools for COVID-19 are scarce, } \\
\text { the use of antibiotics for pneumonia-like symptoms increased and in urban facilities, the use of azithromycin is still frequent [sic]." }\end{array}$ \\
\hline & Upper-middle & "For large hospitals, there was no impact. For smaller hospitals, moderate decrease was observed due to decreasing patient numbers [sic]." \\
\hline & High & $\begin{array}{l}\text { "Preliminary data show slight increase in March/April in watch antibiotics (such as azithromycin/carbapenems) in inpatient settings [sic]." } \\
\text { "We will look at this in more detail, but good data are not yet available." }\end{array}$ \\
\hline \multirow{4}{*}{$\begin{array}{l}\text { Antimicrobial } \\
\text { resistance } \\
\text { rates }\end{array}$} & Low & "Each infection with pathogens avoidable by hygiene for us decreased." \\
\hline & Lower-middle & $\begin{array}{l}\text { "It's too early to comment on impact of increase in use of antimicrobials on AMR during the pandemic, we may have better idea of the } \\
\text { impact on AMR trends over the next couple of years." }\end{array}$ \\
\hline & Upper-middle & "For large hospitals, there was no impact. For smaller, a moderate decrease was observed due to decreasing patient number [sic]." \\
\hline & High & $\begin{array}{l}\text { "The national } 2020 \text { antibiotic resistance data will be available only next year, so it is too early to assess the impact of COVID-19 on AMR } \\
\text { rates. However, the impression is that MDR isolates are more frequent in ICUs caring for COVID patients. Also, decreased sampling in } \\
\text { COVID ICUs, due to the lack of personnel may contribute to underestimating the problem of MDR." }\end{array}$ \\
\hline \multirow{4}{*}{$\begin{array}{l}\text { Long-term } \\
\text { perspectives }\end{array}$} & Low & "If no concerted work is not done to control the spread of AMR it will be another pandemic to hit the world." \\
\hline & Lower-middle & "We need to balance AMR and COVID response activities." \\
\hline & Upper-middle & $\begin{array}{l}\text { "We need to harness the potential of virtual and remote working methods, this will allow us to reach a larger audience with regard to } \\
\text { training of stewardship committee members and health facility workers in their management and surveillance of AMR." }\end{array}$ \\
\hline & High & $\begin{array}{l}\text { "We need to support greater resiliency in antibiotic resistance and antibiotic use programs in healthcare and public health. Because, } \\
\text { without this resiliency, critical AR work will not happen as new threats emerge." } \\
\text { "It is important that pauses in AMR and HCAI surveillance and stewardship activities are short-term and that experienced staff are } \\
\text { supported to resume these activities through recruitment of additional staff for pandemic-related work and investment in infrastructures } \\
\text { that facilitate efficient ways of working and acknowledge remote working requirements, e.g. electronic prescribing, surveillance systems." }\end{array}$ \\
\hline
\end{tabular}


medRxiv preprint doi: https://doi.org/10.1101/2021.03.24.21253807; this version posted March 26, 2021. The copyright holder for this preprint (which was not certified by peer review) is the author/funder, who has granted medRxiv a license to display the preprint in All rights reserved. No reuse allowed without permission.

Figure 1. Likert responses for the impacts of COVID-19 on AMR in GLASS countries (N=73)*

*Only completed responses are shown and respective denominators are shown on the left axis per question. 


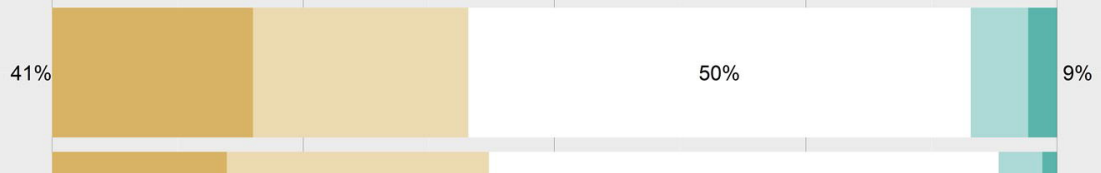

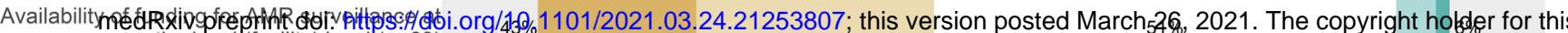

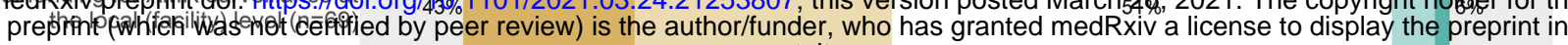

All rights reserved. No reuse allowed without permission.

Proportion of countries reporting: $\square$ Large decrease $\square$ Moderate decrease $\square$ No impact $\square$ Moderate increase $\square$ Large increase

\section{b. Reported impact of COVID-19 on partnerships and oversight for AMR activities}

Ability to work with existing AMR partnerships,

e.g. international, regional laboratory or facility networks $(n=72)$

Ability to create new AMR partnerships, e.g international, regional laboratory or facility networks

Oversight and accountability by national AMR coordinating body of ongoing AMR activities $(n=70)$

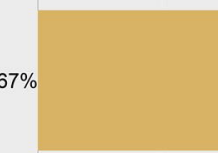

$60 \%$

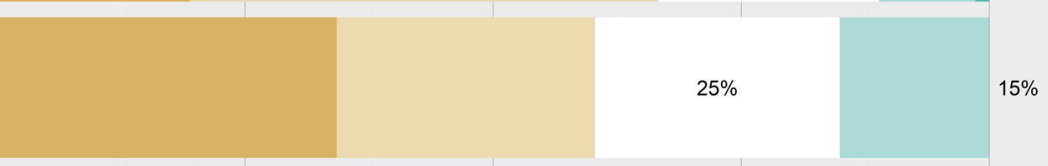

$30 \%$

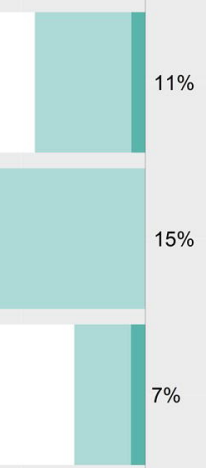

Proportion of countries reporting: $\square$ Large decrease $\square$ Moderate decrease $\square$ No impact $\square$ Moderate increase $\square$ Large increase

c. Reported impact of COVID-19 on diagnostics and laboratory testing for AMR

Number of clinical cultures, i.e. workload of routine microbiology (culture, susceptibility testing) $(n=69$

Number of screening cultures to detect multidrug resistant organisms $(n=68)$

Turn-around time of antimicrobial susceptibility results $(n=70)$

Ability to carry out routine laboratory quality management activities $(n=68)$

Ability to carry out molecular testing, including Whole Genome Sequencing, for multidrug resistant organisms $(n=59)$

Ability to provide training for laboratory personnel $(n=69)$

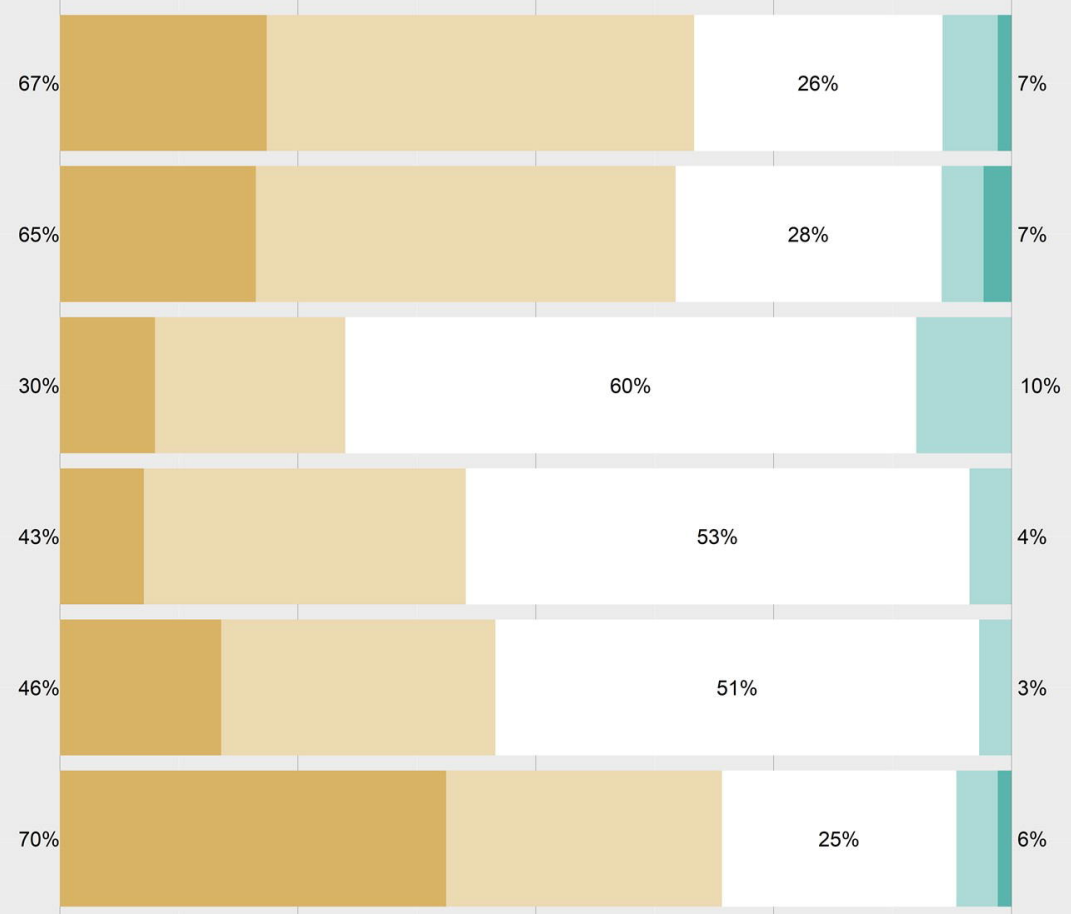

Proportion of countries reporting: $\square$ Large decrease $\square$ Moderate decrease $\square$ No impact $\square$ Moderate increase $\square$ Large increase

d. Reported impact of COVID-19 on laboratory supplies and equipment for AMR activities

Availability of quality laboratory reagents/consumables for bacteriology and antimicrobial susceptibility testing $(n=71)$

Ability of laboratories to service their machines and equipment, e.g. repairs, compliance an updates $(n=67)$

Access to advanced technologies e.g. molecular testing for multidrug resistant organisms $(n=66)$

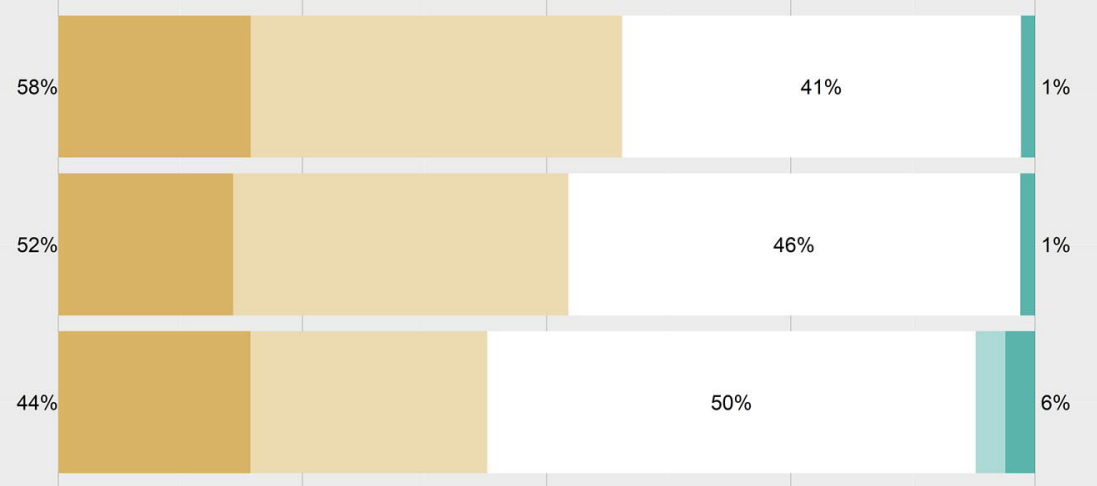

Proportion of countries reporting: $\square$ Large decrease $\square$ Moderate decrease $\square$ No impact $\square$ Moderate increase $\square$ Large increase 
e. Reported impact of COVID-19 on the availability of staff responsible for AMR activities

Availability of public health staff to respond to routine AMR activities, e.g. reporting, outbreak response, including healthcare associated ections, foodbomiteric infections, sexually transmitted diseases $(n=67)$

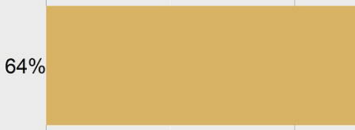

Availability of medical doctors for AMR

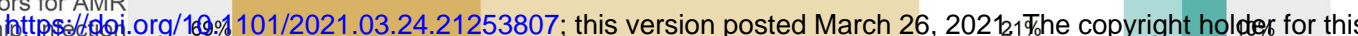
preprint, (whilahamasonoticartified by peer review) is the author/funder, who has granted medRxiv a license to display the preprint in

Availability of nursing staff for AMR activities e.g. stewardship, infection prevention and control $(n=68)$

Availability of infection control focal persons or AMR activi

Availability of environmental/cleaning service workers $(n=67)$

Availability of laboratory staff for AMR diagnostics and testing $(n=68)$

Changes to procedures and infrastructure of laboratory information systems for AMR reporting $(n=72)$

Changes to procedures and infrastructure of hospital clinical information systems for AMR response $(n=67)$

Chronically ill inpatient admissions $(n=64)$

Intensive care unit admissions $(n=67)$

Outpatient visits $(n=68)$

Emergency department visits $(n=67)$

Hospital length of stay $(n=55)$

Occupancy rate of hospital intensive care unit beds $(n=63)$

Non-urgent or elective surgical procedures $(n=66)$

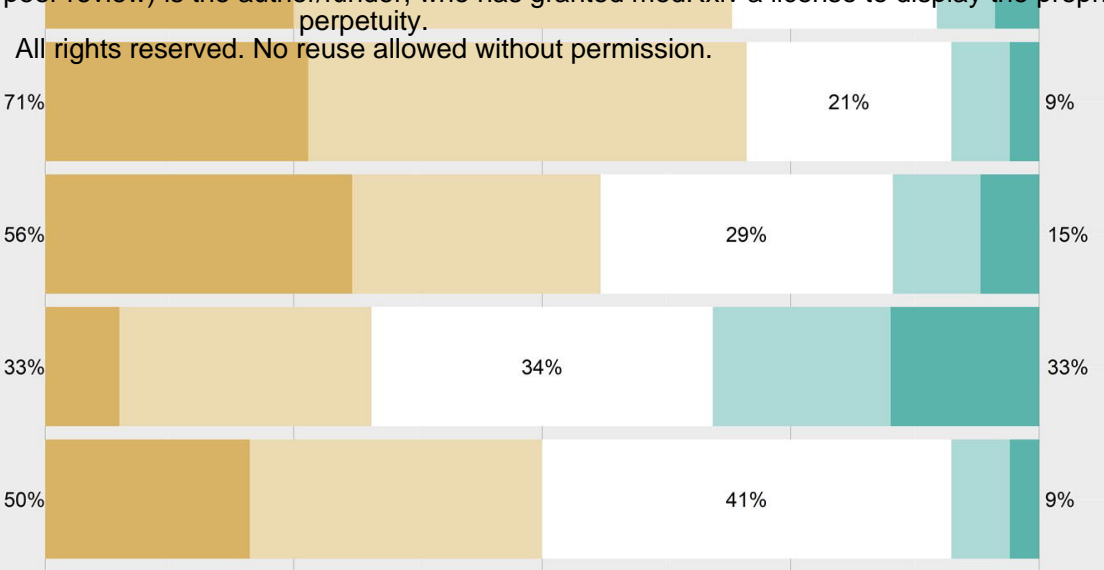

Proportion of countries reporting: $\square$ Large decrease $\square$ Moderate decrease $\downarrow$ No impact $\square$ Moderate increase $\square$ Large increase

f. Reported impact of COVID-19 on AMR data information systems

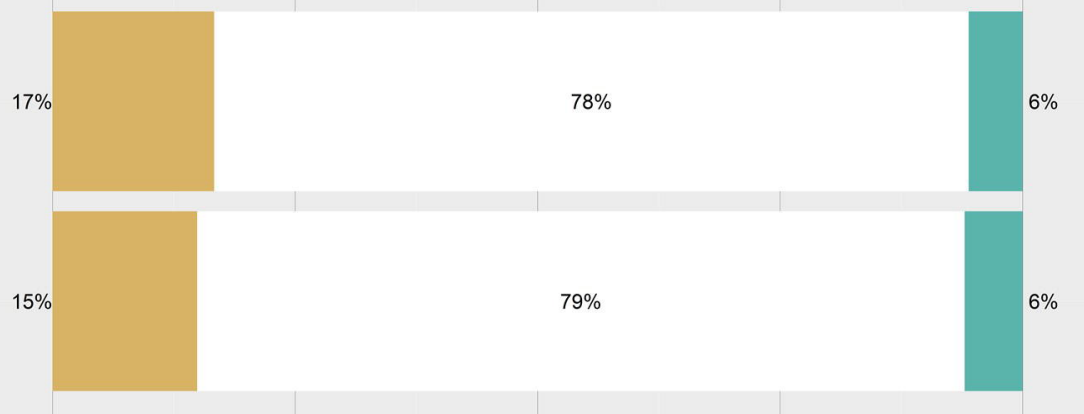

Proportion of countries reporting: $\square$ Moderate change $\square$ No change $\square$ Large change

g. Reported impact of COVID-19 on patient-case mix

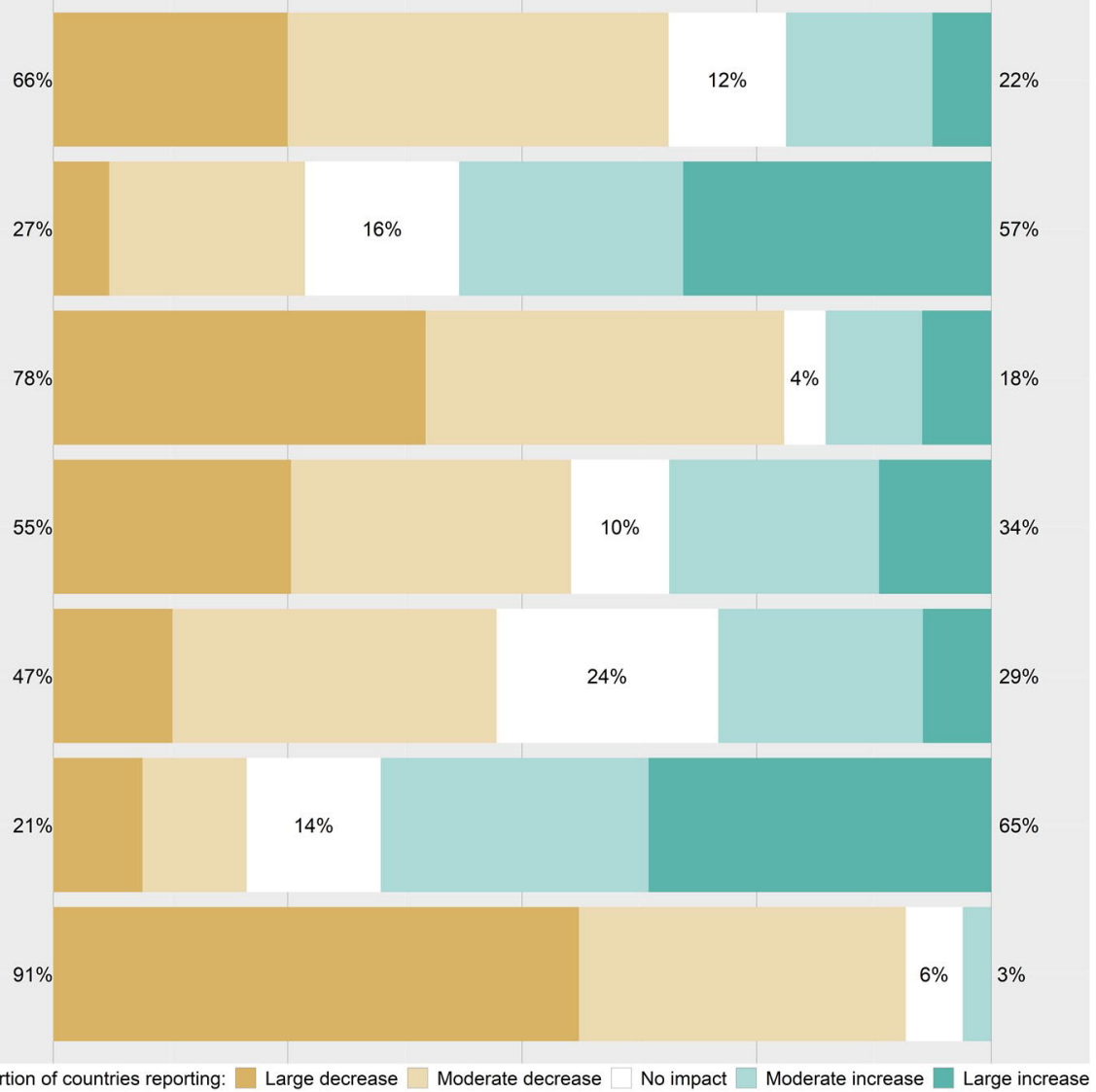


h. Reported impact of COVID-19 on infection prevention and control (IPC) practices Compliance with hand hygiene, e.g. 5 Moments for
hand hygiene $(n=66)$

Availability of alcohol-based hand rub $(n=69)$

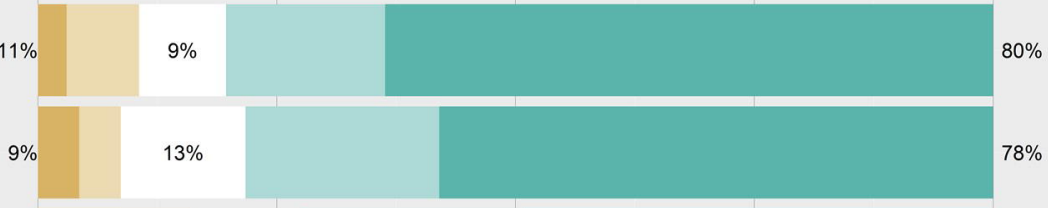

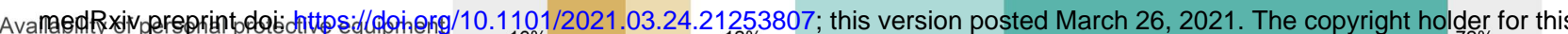

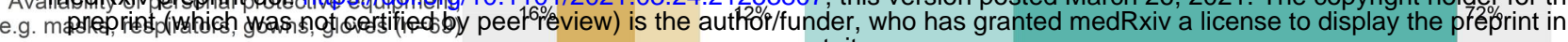

All rights reserved. No reuse allowec triple gowning/gloving, performing hand hygien

Ability to cohort patients by multidrug resistant organism status $(n=55)$

Ability to carry out appropriate IPC practices at long-term care facilities $(n=60)$

Ability to provide IPC training for health care workers $(n=66)$

\section{All rights reserved. No reuse allowed without permission.}
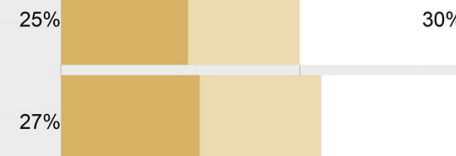
$45 \%$

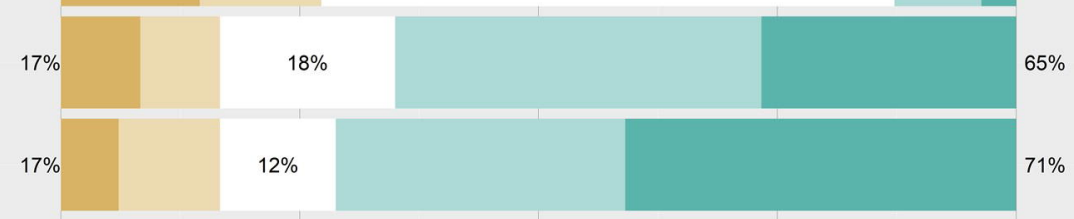

Proportion of countries reporting: $\square$ Large decrease $\square$ Moderate decrease $\square$ No impact $\square$ Moderate increase $\square$ Large increase

i. Reported impact of COVID-19 on antibiotic consumption

Total prescribing of antibiotics $(n=56)$

Availability of antibiotics, i.e. Antibiotic supply chain $(n=58)$

Consumption of WHO access antibiotics $(n=49)$

Consumption of WHO watch antibiotics $(n=47)$

Consumption of WHO reserve antibiotics $(n=45)$

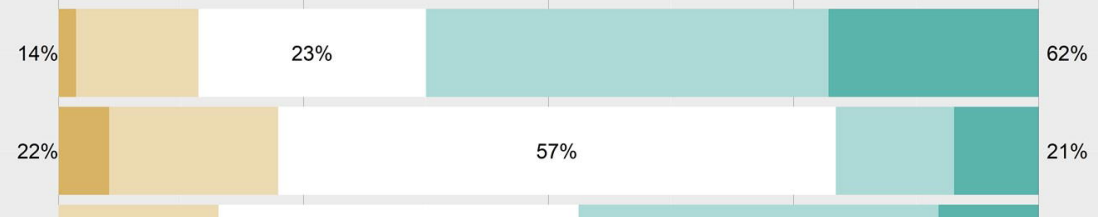

$16 \%$

$37 \%$

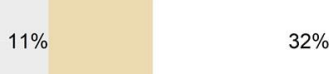

$4 \%$

$56 \%$

Proportion of countries reporting: " Large decrease $\square$ Moderate decrease $\mid$ No impact $\square$ Moderate increase $\square$ Large increase

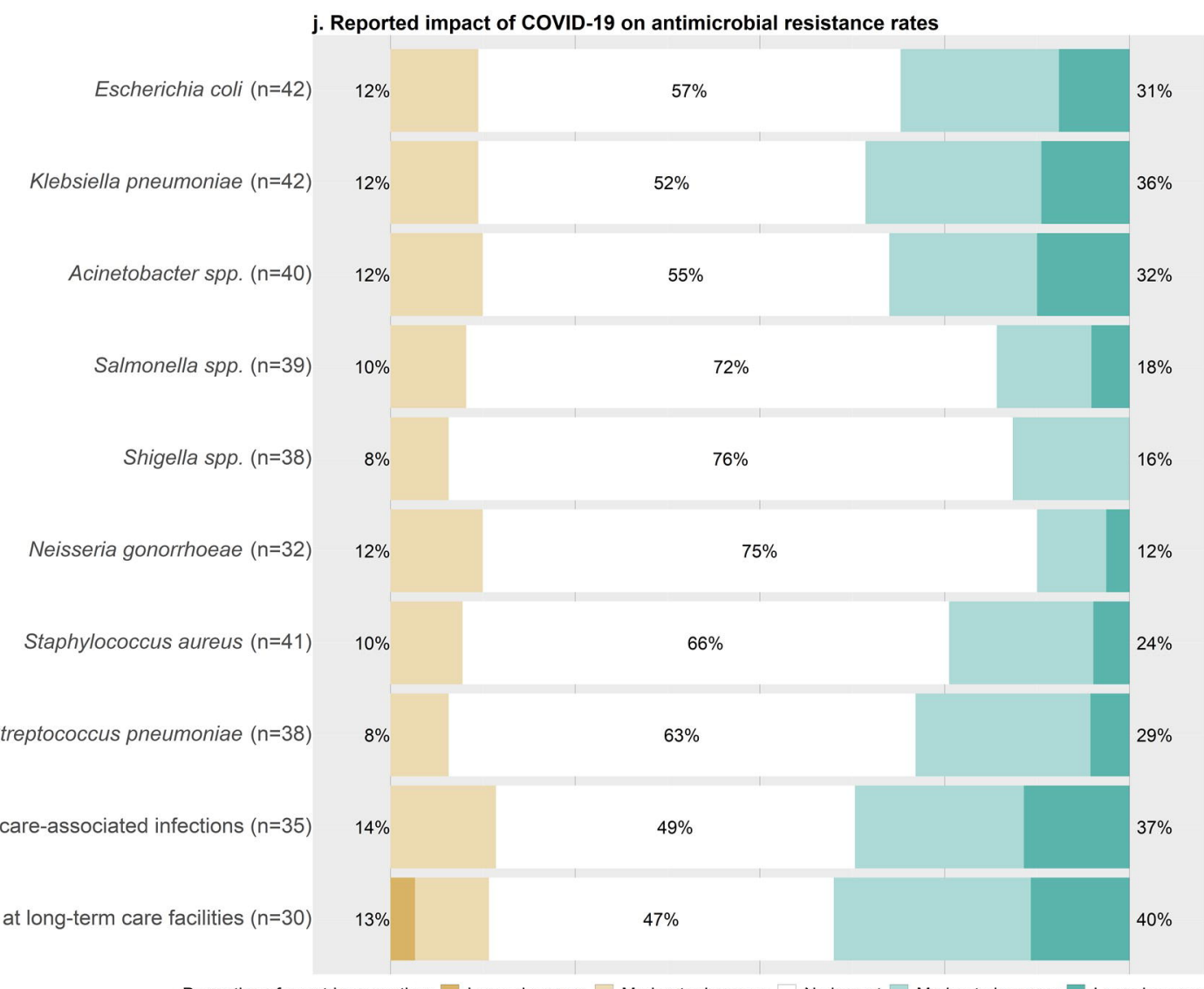

Proportion of countries reporting: $\square$ Large decrease $\square$ Moderate decrease $\square$ No impact $\square$ Moderate increase $\square$ Large increase 